Rocha, L.; Maique, E.T.; Abreu, F.S.B.; Castro, J.R.S.; Oliveira, M.T.C. Área de Proteção Ambiental Municipal do Bororé-Colônia, São Paulo (SP): potencial para práticas de Educação Ambiental e Ecoturismo. Anais do VIII Congresso Nacional de Ecoturismo e do IV Encontro Interdisciplinar de Ecoturismo em Unidades de Conservação. Revista Brasileira de Ecoturismo, São Paulo, v.4, n.4, 2011 , p. 559.

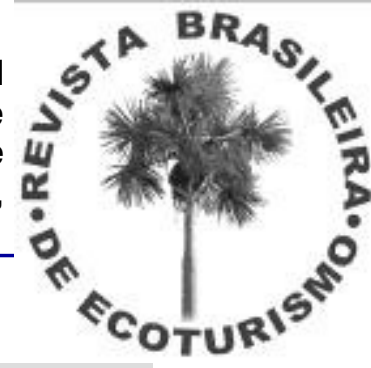

\title{
ÁREA DE PROTEÇÃO AMBIENTAL MUNICIPAL DO BORORÉ-COLÔNIA, SÃO PAULO (SP): POTENCIAL PARA PRÁTICAS DE EDUCAÇÃO AMBIENTAL E ECOTURISMO
}

\section{Lígia Rocha, Estefani Therezia Maique, Fagner Silva Barbosa de Abreu, José Renato da Silva Castro, Marcelo Teixeira Cesar de Oliveira*}

*Instituto Ipá Ti-uá de Meio Ambiente, Cultura e Sociedade

E-mails: ligia_rochas@hotmail.com,te_maykeh@yahoo.com.br, fagnersba@hotmail.com, heavycastro@hotmail.com, marcelotco@ipatiua.com.br

Áreas com grande potencial biológico e hídrico têm sofrido danos com os rápidos processos de ocupação humana, muitas vezes irregular, nas grandes cidades. Uma das medidas para a conservação é a criação de Unidades de Conservação (UC) denominadas Áreas de Proteção Ambiental (APAs). As APAs, diferente da maioria da UCs, são de livre circulação e podem ser constituídas por áreas particulares, possuem certo grau de ocupação humana e são dotadas de atributos abióticos, bióticos, estéticos ou culturais especialmente importantes para a qualidade de vida e o bem-estar das populações humanas. Tem como objetivos básicos proteger a diversidade biológica, disciplinar o processo de ocupação e assegurar a sustentabilidade do uso dos recursos naturais. Em 24/05/2006 a Lei Municipal de no 14.162, criou a APA do Bororé-Colônia no município de São Paulo com a finalidade de proteção dos remanescentes de Mata Atlântica e dos mananciais das represas Billings e Guarapiranga. O objetivo deste trabalho foi identificar as atividades e potenciais para atividades de Educação Ambiental e Ecoturismo na península do Bororé inserida na APA Bororé-Colônia situada na zona sul da cidade de São Paulo. A área escolhida é composta praticamente de área rural protegendo as margens da represa Billings com potencial para turismo e esportes aquáticos. Foram realizadas duas visitas técnicas em julho de 2010 e julho de 2011, o que possibilitou observar a presença de chácaras e sítios, áreas recobertas por vegetação nativa (mata atlântica) e reflorestamentos (Pinus e Eucalyptus). Apesar de o local apresentar relevante beleza cênica, há deposição de resíduos sólidos as margens da represa e outros locais da APA. Verificou-se a ausência de tratamento de esgotos nos córregos que deságuam na Billings. Existe um prédio onde chegou a funcionar um núcleo de Educação Ambiental, mas foi encontrado desativado. Responsáveis pelo local informaram que este não tem previsão de retorno às atividades, no entanto, visitas monitoradas podem ser agendadas na subprefeitura de Parelheiros. Os monitores, capacitados a identificar os pontos de relevância de fauna e flora da APA, estão vinculados a uma agência de turismo credenciada junto a Secretaria do Verde e Meio Ambiente (SVMA). A agência também presta serviços de ecoturismo na vizinha APA Capivari-Monos oferecendo roteiros de trilhas na mata atlântica, cachoeiras, práticas como tirolesa, boiacross, canoagem, rapel, sobrevivência na selva e roteiros históricos-culturais, na cratera de colônia e aldeias indígenas além de estudos do meio. A promoção de atividades de ecoturismo deveria colaborar e funcionar como vetor na promoção e na melhoria da qualidade de vida e da conservação do ambiente, da geração de renda e na ampliação da participação da comunidade, aliados a uma trabalho educativo. No entanto, concluiu-se que embora fosse identificada a presença de uma empresa de turismo, não foram identificadas ações para melhoria da qualidade socioambiental da região induzidas pela atividade de ecoturismo, colaborando para preservar o patrimônio natural e a biodiversidade, bem como a promoção da atividade para trazer benefícios à comunidade local e das atividades educativas com os moradores inseridos na área.

Palavras-chave: Área de Proteção Ambiental, Ecoturismo, Educação Ambiental. 